\title{
DIALOG ANTARA TEOLOGI DAN FILSAFAT Perspektif Teologi Sistematik
}

\author{
Adrianus Sunarko*
}

\begin{abstract}
Abstrak
Pengalaman mengajar teologi selama beberapa tahun menunjukkan adanya kesulitan yang dihadapi banyak mahasiswa dalam melihat relasi antara filsafat dan teologi. Susah payah mempelajari filsafat seringkali dikeluhkan karena tidak dilihat kaitan dan gunanya untuk teologi. Filsafat kadang bahkan dilihat sebagai sesuatu yang mempersulit orang untuk masuk dalam refleksi teologis. Dalam artikel ini berusaha ditunjukkan, bahwa dialog antara filsafat dan teologi sudah memiliki sejarah yang panjang. Melalui contoh-contoh yang konkret hendak diperlihatkan, bahwa bagi teologi dialog dengan filsafat dapat menghasilkan buah yang positif. Untuk itu baik filsafat maupun teologi perlu dijalankan secara konsisten, sesuai dengan prinsip-prinsip metodologis masingmasing ilmu.
\end{abstract}

Kata kunci: filsafat, teologi positiva, teologi spekulativa, dialog, realitas, peristiwa wahyu.

Dalam tulisan berikut saya bermaksud menguraikan aneka bentuk dialog antara teologi dengan filsafat. Karena perspektif yang dipakai adalah teologi, maka perlu dijelaskan terlebih dahulu dua aspek penting dan relevan dari apa yang disebut 'berteologi' itu (I). Setelah itu akan coba diperlihatkan melalui contoh-contoh konkret, bahwa dialog dapat mengambil berbagai macam bentuk yang bervariasi (II). Tulisan ini kemudian akan diakhiri dengan komentar singkat tentang hal-hal yang perlu diperhatikan agar dialog yang dilakukan menghasilkan buah yang bermanfaat (III).

\section{Dua aspek dalam Berteologi}

Berkaitan dengan tema diskusi kita tentang relasi antara teologi dan filsafat (dari perspektif teologi) ini, dua aspek berikut dari kegiatan berteologi perlu mendapat perhatian.

\footnotetext{
* Adrianus Sunarko, Guru besar dalam bidang ilmu teologi pada Sekolah Tinggi Filsafat Driyarkara, Jakarta.
} 
Aspek yang pertama tercermin dari istilah teknis 'teologia positiva' (ponere $=$ meletakkan). Aspek berteologi ini menunjuk pada tugas teologi untuk memaparkan, merumuskan kembali secara sistematis peristiwa wahyu yang merupakan dasar dari iman. Di sini teolog berhadapan dengan sumber-sumber, teks-teks (Kitab Suci, Tradisi, Magisterium) yang diyakini memiliki peran fundamental dalam proses penerusan wahyu. Di samping itu teolog tidak hanya bercerita (teologi narasi saja tidak mencukupi) kembali tentang apa yang tercantum dalam sumber-sumber wahyu, tetapi juga menjabarkan konsekuensikonsekuensi dari apa yang eksplisit disebut maupun implisit terkandung dalam peristiwa wahyu itu. Misalnya, berkaitan dengan paham-paham fundamental tentang realitas (ciptaan, realitas tertinggi dll), tentang manusia, tentang prinsip-prinsip bertingkahlaku, tentang makna hidup dan sejarah, dll. ${ }^{1}$ Peran filsafat yang dapat dibayangkan berkaitan dengan aspek berteologi ini misalnya adalah sebagai berikut:Paham filosofis tentang teks (filsafat bahasa) dapat menentukan prinsip penafsiran atas teks-teks wahyu; Refleksi filosofis tentang nilai Tradisi (misalnya debat antara Gadamer dengan Habermas) turut memberi ilham dalam menentukan sikap teolog tertentu atas tradisi; Sistem berpikir (filsafat) tertentu dapat membantu mengungkapkan kekayaan peristiwa wahyu dengan cara yang tidak ketinggalan jaman, memenuhi standard refleksi ilmiah yang telah dicapai (misalnya dahulu: neo-platonisme, aristotelianisme), menantang teolog untuk memperdalam dan memperbarui pemahamannya tentang peristiwa wahyu (misalnya: kritik Kant tentang makna silih dari salib Yesus Kristus).

\footnotetext{
${ }^{1}$ Yohanes Paulus II misalnya menegaskan, bahwa kekristenan memiliki paham-paham tertentu berkaitan dengan problem kejahatan. Beliau juga menegaskan misalnya, bahwa kekristenan tidak mungkin menyetujui paham materialisme, panteisme. "Masalah kejahatan moral - bentuk kejahatan yang paling tragis - ditanggapi juga dalam Kitab Suci yang menyatakan, bahwa kejahatan itu berasal tidak dari kekurangan materi mana pun, tetapi luka-luka yang ditimpakan oleh pengamalan kebebasan manusia penuh kekacauan. Akhirnya sabda Allah yang menjelma, yakni realisasi sempurna eksistensi manusiawi. Pembacaan ayat-ayat yang kudus menampilkan aspek-aspek lain pada masalah itu. Tetapi muncul dengan jelas ialah: sikap menolak segala bentuk relativisme, materialisme dan panteisme. Keyakinan mendasar "filsafat" yang terdapat dalam Kitab Suci ialah: dunia dan hidup manusia memang mempunyai makna dan mendambakan pemenuhannya, yang terdapat dalam Yesus Kristus." Yohanes Paulus II, Fides et Ratio, Jakarta: DokPen KWI 2009, hlm. 93.
} 
Aspek kedua berkaitan dengan adagium termasyur yang memandang teologi sebagai 'fides quaerens intellectum'. ${ }^{2}$ Aspek ini menunjuk pada upaya teologis untuk memahami (sampai batas tertentu) mengapa peristiwa wahyu de facto begini atau begitu, serta konsekuensikonsekuensi yang diimplikasikan oleh peristiwa wahyu bagi paham tentang realitas, tentang prinsip-prinsip bertingkahlaku, tentang makna hidup dan sejarah dll. Titik berangkat teologi memang adalah peristiwa wahyu (aspek pertama). Aspek kedua ini menunjuk pada tugas teologi untuk mencoba menemukan alasan dari misteri yang diwahyukan. Misalnya: 'Cur Deus Homo'/mengapa Allah menjadi manusia? Mengapa kita mau percaya akan kebangkitan, meskipun tidak ada bukti untuk itu.

Di samping itu aspek kedua ini juga meliputi pekerjaan teolog untuk - dalam dialog - menunjukkan kekhasan paham kristiani bila dibandingkan dengan pandangan agama, budaya lain, filsafat dll, dan menunjukkan relevansi iman kristiani bagi manusia sejaman. Kemungkinan peran filsafat berkaitan dengan aspek berteologi ini misalnya adalah sebagai berikut: filsafat menunjukkan dinamika pencarian manusia tentang hal-hal ultima, paling mendasar, lalu teologi dapat membandingkannya dengan paham-paham teologis tentang hal-hal ultima berdasarkan peristiwa wahyu dan menunjukkan relevansi paham iman kristiani.

\section{Filsafat dalam Berteologi}

Dialog dengan filsafat yang lahir dari kegiatan berteologi yang meliputi dua aspek tersebut ternyata mengambil bentuk yang kompleks dan bervariasi. Contoh-contoh berikut akan memberi ilustrasi secara konkret bahwa dialog itu terjadi baik pada tataran metode maupun berkaitan dengan isi dari teologi itu sendiri.

\section{Dialog dengan Filsafat dan Metode teologi}

Dialog dengan filsafat tertentu dapat memberi inspirasi bagi teolog dalam mengembangkan metode teologi tertentu. Hal itu misalnya

${ }^{2}$ Ensiklik 'Fides et Ratio' memakai istilah 'intellectus fidei'. Bdk. Yohanes Paulus II, Fides et Ratio, hlm. 42. 
dapat dilihat dalam metode teologi transendental Karl Rahner. Dalam salah satu karyanya yang termasyur "Hoerer des Wortes", Rahner pada prinsipnya bertanya tentang "kemungkinan apriori (yang ada pada manusia) untuk dapat mendengar (dan mentaati) wahyu yang mungkin terjadi."3 Dalam karya awal teologi Rahner ini sudah kita temukan apa yang menjadi ciri khas dari (metode) teologi yang terkenal dengan istilah 'teologi transendental' itu. Metode teologi transendental bertanya tentang "keniscayaan persyaratan-kemungkinan (Bedingungen der Moeglichkeit) yang ada dalam pengetahuan dan tindakan subjek/manusia."4 Di sini kita dapat mengenali pengaruh dari filsafat transendental Immanuel Kant. Kalau Kant bertanya tentang prasyarat-prasyarat yang memungkinkan (Bedingungen der Moeglichkeit) pengetahuan kita, Rahner menyelidiki prasyarat-prasyarat yang memungkinkan manusia menjadi pendengar (yang dapat dan harus mematuhi) Sabda yang diwahyukan. Titik berangkatnya tetaplah kebenaran yang disampaikan melalui peristiwa wahyu (misalnya kebangkitan). Dengan bantuan filsafat manusia kemudian secara regresif-transendental diselidiki hal-hal apa yang ada dalam diri manusia yang kiranya akan memungkinkan dia mengimani kebenaran (misalnya: kebangkitan) yang diwahyukan. Seturut teologi transendental, setiap tema teologi dogmatik harus ditunjukkan sisi korelasinya dengan manusia; bahwa dalam diri manusia terdapat prasyarat yang memungkinkannya untuk mendengar dan mempercayai isi wahyu yang direfleksikan dalam teologi dogmatik tersebut. Dengan demikian ditunjukkan relevansi eksistensial dari wahyu kristiani bagi manusia. Isi setiap traktat dogmatik harus ditunjukkan prasyaratkemungkinannya dalam diri manusia. Berkaitan dengan Kristologi misalnya Rahner sampai pada pernyataan yang menimbulkan banyak

\footnotetext{
${ }^{3} \mathrm{~K}$. Rahner, Hoerer des Wortes. Zur Grundlegung einer Religions philosophie (Neu bearbeitet von Johannes Baptist Metz), Freiburg-Basel-Wien: Herder 1971, 21. Bdk. "Was wir trieben, ist eine Anthropologie, insofern wir vom Menschen handelten; ist eine ,theologische" Anthropologie, insofern wir den Menschen begriffen als das Wesen, das in Freiheit in seiner Geschichte auf die moegliche Botschaft des freien Gottes zu horchen hat; sie ist eine'fundamental theologische ${ }^{6}$ Anthropologie, insofern dieses Selbstverstaendnis, das der Mensch von sih hat, die Voraussetzung dafuer ist, dass er die faktisch ergangene Theologie ueberhaupt zu hoeren vermag." K. Rahner, Hoerer des Wortes, 181-182. Bdk. P. Eicher, Offenbarung. Prinzip Neuzeitlicher Theologie, Muenchen: Koesel- Verlag 1977, 347-421.

${ }^{4} \mathrm{~K}$. Rahner, Theologie und Anthropologie, dalam: ders., SchriftenzurTheologie VIII,Einsiedeln/Zürich/Köln: Benzinger 1967, 43-65: 44.
} 
polemik sebagai berikut: "Kristologi adalah antropologi yang mentransendir diri dan antropologi adalah kristologi yang belum sempurna." Bagi orang beriman, model kemanusiaan sejati ada pada Yesus Kristus.

\section{Dialog dengan Filsafat dan Pandangan tentang Tradisi}

Edward Schillebeeckx mendapat inspirasi dari debat antara HansGeorg Gadamer dengan Juergen Habermas tentang Tradisi. Pemahaman kritis Schillebeeckx terhadap Tradisi (Gereja) khususnya dipengaruhi kritik Habermas atas paham (terlalu positif) Gadamer tentang Tradisi. Menurut Habermas, dalam paham positif Gadamer tentang Tradisi terjadi konvergensi antara otoritas tradisi dengan pengetahuan. Tradisi memiliki otoritas karena dilandaskan pada pengetahuan yang benar. Merumuskan pandangan Gadamer, Habermas menegaskan: "Ya, otoritas (tradisi) tidak melulu berkaitan dengan ketaatan (buta), melainkan dilandaskan pada pengetahuan." Sebaliknya Habermas berpandangan, bahwa "Refleksi (akal budi) selalu meninggalkan jejaknya (tidak menerima begitu saja) dalam berhadapan dengan faktisitas norma-norma yang diwariskan."7 Rupanya - demikian kritik Habermas - Gadamer berangkat dari pengandaian, bahwa Tradisi selalu didasarkan pada konsensus yang bebas dan sesuai dengan prinsip-prinsip akal budi; bahwa "setiap konsensus yang terwujud dalam tradisi dalam bentuk/medium bahasa disepakati secara bebas tanpa paksaan."8 Sebaliknya Habermas menegaskan: "Aufklaerung (Pencerahan) mengetahui apa yang dilupakan

\footnotetext{
5 „Christologiea lssichselbst transzendieren de Anthropologie und diesea lsdefiziente Christologie.“ K. Rahner, Schriftenzur Theologie I, Einsiedeln/Zürich/Köln: Benzinger 1967, 184 (catatan kaki 1). Ciri antropologis teologi modern kita lihat pula dalam penegasan Pannenberg berikut: "Makin dapat kita lihat sekarang ini, bahwa dalam sejarah teologi modern pendasaran teologi makin beralih pada pemahaman tentang manusia ... Konsentrasi pendasaran teologis pada antropologi ini sesuai dengan perkembangan refleksi filsafat modern tentang Allah: Filsafat modern makin tegas berpikir tentang Allah sebagai sesuatu yang harus diandaikan demi subjektivitas manusia. Dalam arti itu titik tolak pemikiran tentang Allah adalah manusia dan bukan lagi dunia-semesta. "W. Pannenberg, Anthropologie in theologis cher Perspektive, Göttingen: Vandenhoeck und Ruprecht 1983, 11.

'J. Habermas, Zur Logik der Sozialwissenschaften, Tuebingen: Mohr 1967, hlm. 282.

7J. Habermas, Zur Logik der Sozialwissenschaften, hlm. 285.

${ }^{8}$ J. Habermas, Der Universalitae tsanspruch der Hermeneutik, in: ders., Kultur und Kritik, Frankfurt: Suhrkamp Verlag 1973, 264-301: 296.
} 
Hermeneutika: Bahwa dalam apa yang kita sebut 'perbincangan' (menurut Gadamer: kita adalah perbincangan itu sendiri) terkandung pula relasi kekerasan dan sebenarnya karena itu bukan perbincangan yang sejati ... Klaim universal Hermeneutika hanya dapat berlaku, bila tidak dilupakan, bahwa pewarisan tradisi memang merupakan tempat ditemukannya kebenaran dan saling pemahaman, tetapi juga sekaligus merupakan tempat terjadinya kebohongan dan berlangsungnya kekerasan." Karena itu menurut Habermas, sebuah Hermeneutika yang kritis dan tercerahkan harus "turut memperhitungkan refleksi metahermeneutik tentang prasyarat-prasyarat yang memungkinkan terjadinya komunikasi yang menyimpang." 10 Hermeneutika kritis harus selalu mengajukan pertanyaan, jangan-jangan sebuah konsensus yang dilandaskan pada tradisi tertentu sebenarnya adalah konsensus yang semu dan terpaksa serta merupakan hasil dari (Pseudo-) komunikasi yang menyimpang. Habermas yakin, bahwa "kebenaran hanya dapat diwariskan berdasarkan konsensus yang sejati, yang dibangun atas dasar ideal berupa komunikasi yang menyeluruh dan bebas dari dominasi/paksaan."11 Dari perdebatan Habermas dan Gadamer tersebut Schillebeeckx sampai pada paham yang kritis tentang Tradisi Gereja. "Khususnya sejak tahun enam puluhan, dipengaruhi oleh polemik antara Hans-Georg Gadamer dan Juergen Habermas, sejumlah teolog sampai pada kesimpulan, bahwa sebuah teologi yang murni hermenutis-teoretis dapat mengakibatkan kekeliruan dalam upaya mengaktualkan (iman) ... Pendekatan yang murni teoretis melupakan, bahwa baik dalam tradisi kristiani (yang diwariskan pada kita) maupun dalam situasi aktual sekarang, di mana kita hidup, dapat bersembunyi momen-momen ideologis."12 Menurut Schillebeeckx baik teori Gadamer maupun Habermas memiliki unsur-unsur yang benar. "Kedua metode memiliki dasar yang kuat, karena sejarah nyata kita mencakup unsur benar maupun salah. Hermeneutik sering lupa, bahwa relasi kita dengan masa lalu tidak tanpa masalah dan memuat unsur kritik. Sebaliknya teori kritis seringkali

${ }^{9}$ J. Habermas, Der Universalitae tsanspruch der Hermeneutik, hlm. 295-296.

${ }^{10} \mathrm{~J}$. Habermas, Der Universalitae tsanspruch der Hermeneutik, hlm. 296.

${ }^{11} \mathrm{~J}$. Habermas, Der Universalitae tsanspruch der Hermeneutik, hlm. 297.

${ }^{12}$ E. Schillebeeckx, Theologisch geloofsverstaan anno 1983, Baarn 1983, 17. 
mengabaikan, bahwa pemikiran memiliki relasi asali dengan makna positif yang ditawarkan dan diberikan Tradisi bagi kita."13

Teologi dan Cara Berpikir (Filsafat) yang sepadan dengan Peristiwa Wahyu dan sekaligus relevan bagi orang sejaman

Teolog dapat menemukan dalam filsafat tertentu, kategorikategori/istilah-istilah yang membantu dia dalam upaya merumuskan iman akan peristiwa wahyu secara setia tetapi sekaligus tidak ketinggalan jaman/relevan: Kategori pemikiran yang dimaksud haruslah yang - di satu pihak - dipandang mampu (sampai batas tertentu) mengungkapkan kekayaan peristiwa wahyu dan yang di lain pihak relevan untuk/dapat dimengerti oleh orang sejaman dan tidak berada di bawah standard refleksi yang sudah dicapai akal budi. Contoh: Upaya teologi dalam merumuskan iman akan Allah Tritunggal. Dialog kritis para teolog patristik dengan filsafat yunani menghantar para teolog patristik untuk sampai pada pembedaan antara ousia (hakekat) dan hypostase/prosopon (khususnya ini merupakan jasa dari antara lain ketiga bapa/teolog kapadokia). Kedua istilah itu tidak kita temukan dalam Kitab Suci tetapi pada masa (kritis) itu dipandang memadai untuk merumuskan serta menunjukkan kekhasan paham kristiani tentang Allah Tritunggal yang berbeda dari monoteisme yahudi tetapi sekaligus tidak jatuh pada paham triteisme. ${ }^{14}$ Dialog kritis serupa kita temukan dalam teologi modern. Karl Rahner menolak memakai istilah 'person' untuk Bapa, Putra dan Roh Kudus, karena dalam pemahaman modern - menurut Rahner - konsep person terlalu bernuansa individualistis. Kalau dimengerti secara demikian, kita akan jatuh pada paham triteisme. Bapa, Putra dan Roh Kudus dimengerti sebagai individu yang mula-mula mandiri dan baru kemudian menjalin relasi. Sebaliknya Walter Kasper menyarankan untuk tetap memakai istilah 'person' sambil menegaskan, bahwa konsep itu tidak harus dan tidak selalu dimengerti secara individualistis. Dalam

\footnotetext{
${ }^{13}$ E. Schillebeeckx, Glaubensinterpretation. Beitraege zu einer hermeneutischen und kritischen Theologie, Mainz: Matthias-Gruenewald Verlag 1971, hlm. 143.

${ }^{14}$ Dengan menegaskan bahwa realitas terakhir/tertinggi berciri triniter maka agama kristiani menunjukkan bahwa ia memiliki paham tertentu tentang realitas maupun tentang manusia yang mengacu pada realitas tertinggi. Dalam paham ini konsep "relasi" tidak sekedar bersifat aksiden melainkan merupakan sesuatu yang hakiki/substansial.
} 
konsep person, teologi sendiri perlu menegaskan, bahwa relasi merupakan unsur hakiki. Person sudah selalu ada dalam relasi dan hanya akan mewujudkan diri dalam relasi dengan yang lain. ${ }^{15}$

\section{Dialog dengan Filsafat dan Kekhasan pandangan kristiani}

Dalam dialog dengan berbagai pandangan filosofis, teolog dapat makin menyadari kekhasan pandangan kristiani tentang hal tertentu. Misalnya: Bagaimana sikap kita berkaitan dengan problem ketidakadilan yang merajalela di dunia ini, kegagalan mereka yang berjuang demi keadilan, penderitaan dan kematian mereka yang hidup baik? Berhadapan dengan masalah ini Fjodor Dostojewsky misalnya menolak penjelasan teologis/eskatologis kristiani tentang ganjaran dan pemulihan serta harmoni di surga kelak. Harga yang dibayar untuk itu terlalu mahal dan harmoni itu datang terlambat. "Tambahan pula, keselarasan itu terlalu dilebih-lebihkan; biaya masuknya terlalu mahal bagi kita. Saya sendiri lebih suka mengembalikan karcis masuk saya. Sebagai orang yang lurus, saya bahkan berwajib mengembalikannya secepat mungkin. Dan itulah yang saya lakukan. Saya bukan menolak untuk mengakui Allah, tetapi dengan penuh hormat saya kembalikan kepada-Nya karcis saya." 16 Harmoni di surga di mana si algojo, ibu dan anak yang disiksa akan saling memeluk dan berkata: Engkau benar, Tuhan, harmoni seperti itu ditolak oleh Dostojewsky. Atas nama moral kita tidak boleh berpikir tentang harapan eskatologis di mana penderitaan sekarang kelak akan diberi ganjaran dan didamaikan. Bolehkah terjadi pengampunan kelak atas si algojo yang menyiksa seorang anak? Bolehkah ibu anak itu memaafkan dia? Tidak „Ia sama sekali tidak boleh berniat memaafkannya! Bila ia menginginkannya, maka hanya boleh melakukannya atas namanya sendiri. Ia dapat memaafkan si penyiksa itu atas penderitaan yang ia alami sebagai ibu. Tetapi ia tidak memiliki hak untuk memaafkan penderitaan yang dialami anaknya sendiri ... Ia bahkan juga tidak boleh memaafkannya, apabila anaknya memaafkan algojo itu. Dan bila ia tidak boleh memaafkan, di manakah letak harmoni itu? ...

\footnotetext{
${ }^{15}$ W. Kasper, Der Gott Jesu Christi, Mainz: Matthias-Gruenewald-Verlag 1995, hlm. 347-354. ${ }^{16}$ Sebagaimana dikutip dalam: L. Leahy SJ, Filsafat Ketubanan Kontemporer, Jogjakarta: Kanisius/BPK Gunung Mulia, 1994, hlm. 271.
} 
Tetapi aku tak menghendaki harmoni itu, atas nama cinta pada kemanusiaan, aku tak menghendakinya. Aku ingin tetap bertahan pada penderitaan yang tidak dapat terdamaikan! "17 Max Horkheimer memiliki pandangan yang serupa, meski tak sama. "Tak ada masa depan yang menyembuhkan/menyelamatkan apa yang telah menimpa manusia yang telah lampau. Mereka tidak akan pernah dipanggil kembali untuk diberi ganjaran bahagia dalam kekekalan. Alam dan masyarakat telah melakukan pekerjaannya pada mereka yang telah meninggal itu dan gambaran tentang pengadilan terakhir, di mana kerinduan tak terbatas para tertindas dan mereka yang sudah mati akan dipenuhi, merupakan sisa saja dari cara pikir primitif ..."18

Berhadapan dengan masalah yang sama Walter Benjamin memiliki pandangan sebaliknya. Benjamin berusaha menemukan cara pandang dan pendekatan terhadap sejarah yang tidak mengabaikan solidaritas dengan generasi masa lalu orang-orang tertindas yang sudah meninggal. ${ }^{19}$ Berbeda dari Dostojewsky, Benjamin berpandangan, bahwa secara moral tidak dilarang bila orang berharap akan ganjaran baik dan penghiburan kelak bagi mereka yang ditindas maupun mereka yang meninggal karena sakit dan bencana alam. Sebaliknya secara moral kita wajib untuk terus berharap bahwa tokh masih ada ganjaran dan penghiburan kelak bagi mereka. Dalam rangka itu Benjamin mengintrodusir konsep memoria. Dalam pendekatan kita atas sejarah tidak cukuplah kita bekerja berdasarkan pengetahuan. Kita perlu mendekatinya dengan memoria. Dan dalam tindakan memoria terhadap mereka yang tertindas dan telah mati itu kita akan sampai pada "pengalaman yang melarang kita untuk memaknai sejarah secara a-

\footnotetext{
${ }^{17}$ Seperti dikutip dalam: M. Striet, Versuch über die Auflehnung. Philosophisch-theologis che Überlegungenzur Theodizeefrage, dalam: H. Wagner (Hg.), MitGottstreiten. Neue Zugängezum Theodizeeproblem (= QD 168), Freiburg: Herder, 1998, S. 48-89. 58. Lihat juga: Elie Wiesel: "Saya berharap, bahwa para pembunuh (anak-anak) itu tidak pernah akan dimaafkan. Saya tidak pernah akan setuju, bahwa Allah memaafkan tindakan kejam mereka atas anak-anak itu. " (Seperti dikutip dalam: J.-H., Tück, Christologie und Theodizeebei Johann Baptist Metz. Ambivalenz der Neuzeitim Licht der Gottesfrage, Paderbon/München/Wien/Zürich: Schöningh, 1999, hlm. 255.

${ }^{18}$ Horkheimer, Kritische Theorie I, hlm. 198 (Seperti dikutip dalam: H. Peukert, Wissenschaftstheorie. Handlungstheorie. Fundamentale Theologie: Analysen zu Ansatz und Status theologischer Theoriebildung, Frankfurt am Mainz: Suhrkamp 2009, hlm. 306)

${ }^{19}$ Bdk. H. Peukert, Wissenschaftstheorie, hlm. 307.
} 
teologis, meskipun di lain pihak kita tidak pantas melukiskannya dengan istilah-istilah teologis." 20 Tentu Benjamin sadar, bahwa memoria tidak berarti tindakan penyelamatan. Memoria atas mereka yang telah meninggal adalah sebuah tindakan manusia, dan tidak membawa keselamatan. Untuk itu dibutuhkan Allah. Tetapi kebutuhan akan Allah tetap tidak menjamin eksistensi-Nya. ${ }^{21}$ Kita melihat di sini, bagaimana Benjamin berusaha tetap pada jalur berfilsafat dan tidak berteologi. Tetapi sebenarnya - menurut Horkheimer - pernyataan Benjamin itu selain bersifat idealistis, ${ }^{22}$ juga sudah melintas menjadi pernyataan teologis. Dalam salah satu suratnya pada Benjamin ia menulis. "Pada akhirnya pernyataan anda (tentang hal itu) adalah pernyataan teologis."23

Dalam komentarnya atas diktum terkenal dari Max Horkheimer ("Einen unbedingten Sinn zu retten ohne Gott, ist eitel"), ${ }^{24}$ Habermas membuat pembedaan penting antara makna filosofis tentang kemutlakan (sebuah tuntutan moral) di satu pihak dengan kemutlakan makna/makna terakhir sebagaimana ditawarkan oleh agama di lain pihak. Berdasarkan konsepnya tentang „Transzendenz von innen“625 Habermas mengembangkan gagasan, bahwa rasio komunikatif dapat sampai pada paham tentang berlaku mutlaknya sebuah tuntutan etis/moral (misalnya menghormati martabat tiap orang), tanpa perlu mengandaikan adanya makna terakhir dari prinsip itu (apakah tindakan itu akan mendapatkann

\footnotetext{
${ }^{20}$ W. Benjamin, Passagen (Seperti dikutip dalam H. Peukert, Wissenschaftstheorie, hlm. 307).

${ }^{21}$ Kebutuhan ontologis akan adanya Allah, sama sekali tidak menjamin bahwa Ia memang ada. Th. Adorno menulis: "Das ontologische Beduerfnis allein garantiert so wenig, was es will, wie die Qual der Verhungernden die Speise”. (Seperti dikutip dalam: Magnus Striet, Das Versprechen der Gnade, dalam: Th. Proepper, Theologische Anthropologie. Zweiter Teilband,Freiburg-Basel-Wien: Herder Verlag 2011, 1490-1520:. 1506).

22"Die Feststellung der Unabgeschlossenheit ist idealistisch, wenn die Abgeschlossenheit nicht in ihr aufgenommen ist. Das vergangene Unrecht ist geschehen und abgeschlossen. Die Erschlagenen sind wirklich erschlagen." Horkheimer, Brief vom 16.3.1937 an Benjamin (Seperti dikutip dalam H. Peukert, Wissenschaftstheorie,305).

${ }^{23}$ Horkheimer, Brief vom 16.3.1937 (Seperti dikutip dalam H. Peukert, Wissenschaftstheorie, hlm. 307).

24J. Habermas, Zu Max Horkheimers Satr: <<Einen Unbedingten Sinn zu retten ohne Gott, ist eitel<<, in: J. Habermas, Text und Kontexte, Frankfurt am Main: Suhrkamp Verlag, 1992, hlm. 110-126.

25J. Habermas, "Transzendenz von innen: Lebensweltliche und archaische Bewaeltigung des Dissensrisikos", in: Faktizität und Geltung. Beiträge zur Diskurstheorie des Rechts und des demokratischen Rechtsstaats, Frankfurt am Main : Suhrkamp Verlag 1992, hlm. 32-44.
} 
ganjaran berupa kebahagiaan atau tidak). Hal terakhir ini merupakan wilayah agama. Khususnya Habermas ingat pada diskusinya dengan Helmut Peukert ${ }^{26}$ berhadapan dengan kenyataan penderitaan dan kematian mereka yang merupakan korban sejarah, korban ketidakadilan. Agama dan teologi di situ dapat berbicara tentang Allah dan kebangkitan dan dengan demikian memelihara harapan (tetapi tidak atas dasar pengetahuan), bahwa ketidakadilan bukanlah yang terakhir. Filsafat dapat pula tergoda untuk kembali ke metafsika (tradisional) dan memainkan peran sebagai penghibur. Tetapi kalau konsekuen berpikir postmetafisik demikian posisi filosofis Habermas -, filsafat tidak boleh tunduk pada godaan tersebut. "Berhadapan dengan masalah penderitaan yang tak terhindarkan, ketidakadilan ..., kontingensi yang dialami dalam penderitaan, kesepian, sakit dan kematian, filsafat postmetafisik tidak dapat menyediakan penghiburan sebagaimana dapat dilakukan oleh agama dengan mengajarkan, bagaimana dapat menanggung semua itu dalam terang yang lain." ${ }^{27}$ Juergen Habermas mengakui, bahwa ada sesuatu yang hilang, ketika "paham (teologis) tentang berdosa berubah melulu menjadi paham (etis) bersalah, tindakan melawan perintah Allah diubah menjadi tindakan melawan perintah manusiawi belaka." Karena "dalam keinginan kita untuk menyesal dan minta maaf, terkandung juga kerinduan untuk meniadakan kembali penderitaan yang telah kita sebabkan pada orang lain." Demikian pula bagi manusia sungguh menggelisahkan mengingat "penderitaan orang-orang di masa lalu yang irreversibel/tak dapat dipulihkan kembali - mereka yang mengalami ketidakadilan, mereka yang tanpa salah diperlakukan dengan kejam, dihina dan dibunuh. Akan tetapi: memulihkan situasi buruk seperti itu merupakan hal yang melampaui kemampuan manusia." Habermas menegaskan: "hilangnya harapan akan kebangkitan meninggalkan kekosongan yang sungguh terasa.,"28

\footnotetext{
${ }^{26}$ J. Habermas, Replik auf Einwände.Reaktion auf Anregungen, in: R. Langthaler/H. NaglDocekal (Hrsg.), Glauben und Wissen. Ein Symposium mit Jürgen Habermas, Wien-Berlin: Oldenbourg-Akademie Verlag, 2007, 366-414: 406.

${ }^{27}$ J. Habermas, Zu Max Horkheimers Satz: "Einen unbedingten Sinn zu retten ohne Gott, ist eitel”, hlm. 125.

${ }^{28}$ J. Habermas, Glauben und Wissen. Friedenspreisrede des Deutschen Buchbandels 2001(Seperti dikutip dalam: M. Striet, Das Versprechen der Gnade, hlm. 1503).
} 
Berhadapan dengan aneka pandangan filosofis seperti di atas seorang teolog dapat mengenali kembali pergulatan dan pertanyaanpertanyaan yang serupa yang ia hadapi juga sebagai manusia beriman. Dengan membaca sumber-sumber teologinya, ia kemudian dapat merumuskan pandangan kristiani tentang hal yang sama, menemukan adanya keserupaan keprihatinan dengan pandangan-pandangan tersebut di atas tetapi juga makin menyadari kekhasan pandangan kristiani. Mungkin ia dapat bersyukur, bahwa atas dasar wahyu ia dapat berbicara tentang kebangkitan (yang disesalkan hilangnya oleh Habermas) dan kemungkinan harmoni di surga (sambil juga bersama Dostojewsky diganggu oleh pertanyaan "mengapa harmoni dan pemulihan itu baru terjadi kelak?") Tetapi karena sadar, bahwa pernyataan teologis tentang kebangkitan tidak didasarkan pada pengetahuan melainkan pada iman dan harapan, maka ia sama sekali tidak dapat menilai filsafat Habermas misalnya sebagai buruk, hanya karena tidak lagi memberi tempat pada kebangkitan dalam filsafatnya.

\section{Diskusi dengan Filsafat dan Perkembangan Teologi}

Pandangan filosofis tertentu dapat menantang Teolog untuk memikirkan iman secara baru, mendorongnya (bahkan "memaksa") untuk mengoreksi pandangan teologis tertentu, membantu teologi menemukan kekayaan peristiwa wahyu yang selama ini belum disadari. Beberapa contoh berikut dapat memberi ilustrasi tentang apa yang dimaksudkan tersebut:

a. Seperti kita ketahui, ketika refleksi filsafat modern tentang martabat manusia berujung pada lahirnya paham tentang Hak Asasi Manusia, mula-mula Gereja bersikap menolak. Paham Hak Asasi Manusia dipandang tidak sesuai dengan kekristenan. Sejalan dengan bergulirnya waktu Gereja kemudian mengoreksi sikap dan pandangannya sendiri dan menerima paham Hak Asasi Manusia sebagai sesuatu yang tidak bertentangan dengan paham kristiani tentang Allah dalam relasi-Nya dengan manusia. Salah satu bukti paling jelas dari perubahan sikap itu tampak dalam penegasan Konsili Vatikan II tentang kebebasan beragama (bdk. Dignitatis Humanae). Sebenarnya penerimaan paham hak asasi 
manusia ini memiliki konsekuensi yang jauh bagi teologi. Dan pada hemat saya, memberi pendasaran teologis yang komprehensif dan konsisten atas pengakuan akan Hak Asasi Manusia tersebut masih merupakan pekerjaan rumah yang besar bagi para teolog.

b. Kritik Kant atas pandangan kristiani tentang silih: Di satu pihak kita mengenal Kant sebagai filsuf yang sangat mengagumi Yesus Kristus sebagai tokoh dengan kualitas moral sempurna. Demikian pula ia memuji bahagia orang kristiani karena Kitab Suci yang dimilikinya memenuhi standard moral yang tinggi. "Berbahagialah! Bila Buku (KS) yang sampai ke tangan manusia seperti itu memuat ajaran agama tentang prinsip moral yang murni secara lengkap. ${ }^{, 29}$ Di lain pihak ia melontarkan kritik pedas terhadap paham teologis tentang sengsara dan wafat Yesus di salib sebagai silih bagi dosa-dosa seluruh umat manusia. Berdasarkan kepekaan etis subjek modern tentang tanggung-jawab yang harus dipikul sendiri atas dosa-dosanya, Kant menyetujui mereka yang mengkritik paham silih tersebut sebagai semacam "takhayul" 30 . Untuk mengimani paham "Kristus yang menjadi silih atas dosa menggantikan manusia" itu orang harus mengabaikan akal budi. Akal budi harus mengadakan "salto mortale."31 Menurut Kant ajaran tentang silih ini termasuk bagian dari ajaran dari Gereja yang seiring dengan jalannya waktu pasti akan ditinggalkan, khususnya ketika agama-akal budi mulai datang. ${ }^{32}$ Kritik tajam atas paham sentral teologi kristiani itu menantang para teolog untuk menguji kembali nilai soteriolgis dari peristiwa Yesus Kristus. Sejumlah teolog kemudian sampai pada pemaknaan baru, merelatifkan paham silih tersebut (misalnya: Karl Rahner, Edward Schillebeeckx): Yesus Kristus - dalam kesatuan Allah Trinitaris - adalah Penyelamat kita. Tetapi sebagai Penyelamat, Ia tidak dimengerti lagi terutama sebagai

\footnotetext{
${ }^{29}$ I. Kant, Die Religion innerbalb der Grenzen der blossen Vernunft (Hrsg. v. Rudolf Mater), Stuttgart: Philipp Reclam Jun 1974, hlm. 139.

${ }^{30}$ I. Kant, Die Religion, hlm. 156.

${ }^{31}$ I. Kant, Die Religion, hlm. 159 (Bdk. Karl-Heinz Menke, Stellvertretung. Schlüsselbegriff christlichen Lebens und theologische Grundkategorie, Einsiedeln-Freiburg: Yohanes Verlag 1997, hlm. 96).

${ }^{32}$ Peralihan menuju agama-akal budi itu disebut Kant sebagai datangnya Kerajaan Allah ("Der Allmaehliche Uebergang des Kirchenglaubens zur Alleinherrschaft des reinen Religionsglaube ist die Annaeherung des Reichs Gottes.”) I. Kant, Die Religion, hlm. 150.
} 
yang melakukan silih atas dosa-dosa. ${ }^{33}$ Dalam kerangka pencarian manusia modern akan makna hidup dan dalam upaya subjek modern untuk merealisasikan diri, Yesus tidak menjadi silih bagi manusia. Ia memberi contoh dan sekaligus memungkinkan manusia untuk menemukan, bahwa perwujudan dan aktualisasi diri manusia justru terlaksana dalam praktek radikal mencintai sesama dalam iman dan harapan akan Allah yang lebih kuat dari maut. Pemaknaan teologis secara baru tersebut tentu saja tidak sekedar demi mengikuti mode. Teolog tidak boleh lupa menguji pandangannya kembali pada sumber-sumber wahyu kristiani. Aspek ini dengan sangat tegas diingatkan misalnya oleh Ratzinger dalam bukunya yang terbaru tentang Yesus Kristus. Setelah merefleksikan kritik modern terhadap paham silih di atas serta setelah menyampaikan penafsirannya sendiri tentang hal tersebut, Ratzinger/Benediktus XVI mengingatkan: "Misteri tentang silih tidak boleh dikorbankan sama sekali demi Rasionalisme yang sok tahu (Das Geheimnis der Suehne darf keinem besserwisserischen Rationalismus geopfert werden) ... 'Anak Manusia ... datang bukan untuk dilayani, melainkan untuk melayani dan untuk memberikan nyawa-Nya menjadi tebusan bagi banyak orang' (Markus 10: 45)."34

c. Tekanan yang diberikan J.B.Metz pada Praxis pada fase kemudian dari teologinya harus kita pahami sebagai jawaban Metz atas ideologi kritik para Marxis. Kritik bahwa agama dan teologi tidak lain merupakan cerminan saja dari hubungan (tidak adil) yang ada pada tataran konkret sosial ekonomi, hanya dapat dijawab bila potensi praktis dari ajaran biblis tentang iman dan masa depan secara konkret diwujudnyatakan dalam tindakan menciptakan dunia yang lebih manusiawi. Kita ingat di sini akan tesis kesebelas Marx tentang Feuerbach: „Para filosof telah banyak memberi penafsiran atas dunia, padahal yang penting adalah mengubahnya. ${ }^{\text {(35 }}$ Praxis kristen konkret memerangi keterasingan dan

\footnotetext{
${ }^{33}$ Dalam jilid kedua dari bukunya tentang Yesus dari Nasaret, Ratzinger/Benediktus XVI berusaha memberi penafsiran baru tentang problem silih ini. Bdk. Joseph Ratzinger/Benedikt XVI, Jesus von Nazareth. Band II. Von Einzug in Jerusalem bis zur Auferstehung, Freiburg/Basel/Wien: Herder 2011, hlm. 254-264. 34J. Ratzinger/Benedikt XVI, Jesus von Nazareth. Band II, hlm. 264.

${ }^{35}$ Sebagaimana dikutip dalam J.-H. Tück, Christologie und Theodizee bei Johann Baptist Metz, hlm. 96-97.
} 
ketidakadilan dalam masyarakat lah merupakan cara terbaik untuk membuktikan bahwa kritik agama para marxis tidak benar. Akan tetapi, dalam upaya mewujudkan janji Injil tentang keadilan dan kebebasan dan perdamaian, Metz tidak berangkat dari berbagai macam program positif yang mempropagandakan emansipasi. Program atau proyek utopis tersebut biasanya cenderung mensahkan korban tertentu demi masa depan. Upaya mewujudkan masyarakat yang lebih manusiawi harus dimulai dari/berangkat dari kenyataan Humanum yang terancam, dari penderitaan dan ketidakadilan. ${ }^{36} \mathrm{Di}$ satu pihak gagasan ini mendapat inspirasinya dari pemikiran Adorno tentang dialektika negatif. Pertemuan kita dengan sesuatu yang negatif, dengan penderitaan menunjukkan kepada kita secara evidens, apa yang harus kita lakukan demi masa depan: bahwa yang negatif itu harus diubah. Di lain pihak ajaran biblis tentang eskatologi juga memainkan peran yang penting di situ. Metz menegaskan, bahwa janji akan kebebasan, keadilan dan perdamaian sebagaimana kita temukan dalam kitab suci tidak pernah dapat kita identikkan dengan keadaan aktual yang dicapai masyarakat di dunia ini, kapanpun juga. "Kemungkinan terjadinya kesesatan secara kolektif tetaplah belum lenyap.",37

Untuk dengan tepat memahami gagasan Metz pada periode awal teologi politik ini, baiklah kita secara tegas membuat perbedaan antara harapan eskatologis kristen dengan harapan utopis modern. Jangkauan harapan eskatologis kristen melampau horison sejarah manusia. Harapan utopis modern akan masa depan memang melampaui keadaan aktual masyarakat, akan tetapi tetap tinggal dalam perspektif sejarah di dunia ini. Pembedaan itu penting, karena kalau tidak, ada bahaya bahwa ajaran kristen tentang harapan eskatologis diselewengkan dan diidentikkan dengan harapan utopis modern di dunia ini. Konkret, itu berarti bahwa orang tergoda untuk mewujudkan harapan eskatologis itu di dunia ini, dan kalau perlu kekerasan pun dihalalkan.

\footnotetext{
${ }^{36}$ J.B. Metz, Zur Theologieder Welt, Mainz: Matthias-Gruenewald Verlag 1985, hlm. 115.

${ }^{37}$ J.B. Metz, Zur Theologie der Welt, hlm. 116.
} 


\section{Bersama aliran filsafat tertentu memberi pandangan kritis atas pandangan aktual tertentu}

Dialog dengan filsafat dapat juga berujung pada pembentukan sikap kritis bersama dalam menanggapi pandangan yang sedang menjadi trend dalam masyarakat. Hal itu dapat kita lihat misalnya dalam dialog antara J. Ratzinger dengan J. Habermas serta dialog antara J.B. Metz dengan W. Benjamin.

a. Dialog antara Ratzinger/Benediktus XVI dengan Juergen Habermas: Paus Benediktus XVI dalam ceramahnya di Regensburg melontarkan kritik sebagai teolog atas konsep akal budi dan kebebasan modern sebagaimana de fakto berkembang, antara lain dengan menunjuk pada konsekuensi-konsekuensi negatif yang disebabkannya. Kritik itu terutama diarahkan pada ditinggalkannya sintesis antara iman dan akal budi (pengetahuan). Dalam perkembangan selanjutnya konsep modern tentang akal budi itu sendiri terus merosot dan mengalami penyempitan. Paham tentang akal budi kehilangan dimensi metafisisnya dan dibatasi hanya pada akal budi praktis serta apa yang secara teknis dapat diperhitungkan. "Apa yang ilmiah semata-mata diukur dari kepastian berdasarkan sintesis pengetahuan dari matematika dan ilmu-ilmu empiris ... Dengan demikian kita sebenarnya sedang berada dalam proses penyempitan radius atau jangkauan dari pengetahuan dan akal budi. Hal tersebut harus dikritik dan dipersoalkan." 38 Paham seperti itu harus dikritik bukan hanya karena Allah lalu tidak mendapat tempat, melainkan dengan demikian paham tentang manusia pun diperkurus. Pertanyaan-pertanyaan mendasar tentang dari mana dan ke mana tujuan hidup, tentang agama dan etika tidak lagi masuk dalam forum ilmiah yang dapat didiskursuskan berdasarkan akal budi bersama-sama. Problem itu diserahkan pada selera subjektif masing-masing. „Masing-masing subjek lalu memutuskan berdasarkan pengalamannya, apa yang nampak cocok bagi hidup religius/keagamaannya. Dan suara hati subjektif menjadi satu-satunya instansi etis terakhir. Dengan demikian Etika dan Agama kehilangan

${ }^{38}$ Benediktus XVI, Glaube, Vernunft und Universitaet. Erinnerungen und Reflexionen, dalam: http://www.zenit.org/article-10336. Diakses pada hari Senin, 18 Juni 2007, pukul 11.35 WIB. 
perannya dalam membangun kebersamaan dan kita jatuh ke dalam relativisme. ${ }^{639}$ Kritik atas penyempitan jangkauan akal budi tersebut tidak baru. Sudah sebelum menjadi Paus, Ratzinger melontarkan kritik yang sama.,,Kalau dahulu misalnya masih dibedakan antara rasio dan intelektus; antara akal budi dalam kaitan dengan yang empiris ... dan akal budi yang berkaitan dengan lapisan lebih mendalam dari Ada, sekarang yang berlaku hanyalah rasio dalam arti sempit. Hanya yang dapat diverifikasi, atau lebih tepat: difalsifikasi yang dianggap selaras dengan akal budi. Akal budi direduksi pada yang secara empiris dapat diuji. Seluruh wilayah moral dan agama masuk hanya dalam wilayah yang subjektif.“ $“ 40$

Bahwa kritik seperti itu bukanlah pandangan seorang teolog saja, kelihatan dari kenyataan, bahwa hal tersebut - dengan motif yang berbeda - juga dikeluhkan oleh dunia filsafat sendiri. Kritik terhadap penyempitan makna akal budi itu (gejala ini nampak dalam meluasnya sikap skeptis terhadap kebenaran, mundurnya kepercayaan pada kemampuan akal budi) misalnya dilontarkan pula oleh Habermas (tentu saja dengan usulan tentang pemecahan yang berbeda dari Benediktus XVI). "Di satu pihak saya mengkritik aufklärung yang belum dicerahkan yang menyangkal segala kebenaran yang ada dalam agama. Tetapi juga saya tak sependapat dengan Hegel yang baginya agama adalah

\footnotetext{
${ }^{39}$ Benediktus XVI, Glaube, Vernunft und Universitaet. Erinnerungen und Reflexionen, dalam: http://www.zenit.org/article-10336. Diakses pada hari Senin, 18 Juni 2007, pukul 11.35 WIB. Di lain pihak, kritik yang dilontarkan bukanlah kritik negatif melulu yang mengajak kita untuk kembali ke jaman pra-modern, pra-aufklaerung. „Upaya kritik diri atas akal budi modern di atas ... sama sekali tidak bermaksud mengatakan, bahwa sekarang kita harus kembali ke jaman sebelum jaman pencerahan dan meninggalkan modernitas... Di sini saya tidak bermaksud melontarkan kritik negatif. Saya menegaskan perlunya perluasan kembali konsep kita mengenai akal budi ... Karena kendati kita bergembira atas berbagai kemungkinan baru yang diperoleh manusia, kita juga melihat ancaman-ancaman yang terus muncul yang lahir dari berbagai kemungkina baru tersebut. Karena itu kita harus bertanya, bagaimana kita dapat tetap menjadi Tuan yang mengarahkan perkembangan. Kita hanya dapat melakukannya, bila akal budi dan iman secara baru kembali diintegrasikan; bila kita mengatasi penyempitan makna akal budi pada yang dapat difalsifikasi dalam eksperimen dan kembali memperluas cakupan makna akal budi seluas mungkin ..." Benediktus XVI, Glaube, Vernunft und Universitaet. Erinnerungen und Reflexionen, dalam: http://www.zenit.org/article-10336. Diakses pada hari Senin, 18 Juni 2007, pukul 11.35 WIB.

${ }^{40}$ Bdk. J. Ratzinger, Werte in Zeiten des Umbruchs. Die Herausforderungen der Zukunft bestehen, Freiburg/Basel/Wien: Herder Verlag, 2005, hlm. 132.
} 
perwujudan dari Roh yang berada dalam bentuk pemikiran sebelum filsafat .... Motif dari refleksi saya tentang masalah iman dan pengetahuan adalah keinginan untuk memobilisasi akal budi modern melawan kemerosotannya sendiri. "41 Masalah kemerosotan akal budi itu tampak dalam apa yang oleh Habermas disebut sebagai „radikalisasi postmodern atas dialektika pencerahan serta naturalisme." 42

Kritik Habermas atas posisi para pemikir postmodern sudah kita kenal. Pemecahan yang ditawarkan teori-teori postmodern ditolak Habermas, karena menurut dia kritik mereka terhadap paham akal budi modern terlalu radikal. Mereka memandang masalah yang dihadapi sebagai "logical outcome of the program of a self-destructive intellectual and societal rationalization." 43 Sementara Habermas melihat krisis modern sebagai akibat dari dominasi paham selektif tertentu dari akal budi, sehingga sebenarnya pada akal budi itu sendiri masih terdapat potensi untuk keluar dari krisis. Kritik para pemikir postmodern adalah total dan terwujud dalam meluasnya sikap skeptis terhadap kemampuan akal budi untuk mencari kebenaran. Habermas tetap yakin berpegang pada sikap untuk meneruskan proses modernisasi, tetapi tentu saja dengan koreksi. Kritiknya terhadap akal budi modern tidak total. Di sini kiranya Habermas melihat perlunya memberi perhatian pada agama; bukan semata-mata sebagai fakta yang secara sosial ternyata masih ada. "Philosophy must take this phenomenon seriously from within ... as a cognitive challenge." 44

Adapun naturalisme yang dicemaskan Habermas adalah naturalisme yang saintistik yang sebagai pandangan hidup meredusir ,segala yang dapat dimengerti dan dialami pada apa yang dapat diamati

\footnotetext{
${ }^{41} \mathrm{~J}$. Habermas, Ein Bewusstsein von dem, was feblt. Über Glauben und Wissen und den Defätismus der modernen Vernunft, dalam: K. Wenzel (Hrsg.), Die Religion und die Vernunft. Die Debatte um die Regensburger Vorlesung des Papstes, Freiburg/Basel/Wien: Herder Verlag, 2007, 47-56: 50-51.

${ }^{42}$ J. Habermas, Ein Bewusstsein von dem, was fehlt, hlm. 51.

${ }^{43}$ J. Habermas, Pre-political Foundations of the Democratic Constitutional State?, in: J.Habermas/J. Ratzinger, The Dialectics of Secularization. On Reason and Religion (Translated by Brian McNeil, C.R.V.), San Francisco: Ignatius Press, 2006, 19-52: 37.

${ }^{44}$ J. Habermas, Pre-political Foundations, hlm. 38.
} 
(dengan indera). “45 Tentu saja seturut kritik Kant atas Metafisika tradisional dan sebagai pemikir yang postmetafisik, Habermas setuju dengan pandangan bahwa kita tak dapat lagi membuat pernyataan ontologis yang dapat dipertanggungjawabkan secara ilmiah tentang ,ada secara keseluruhan." ${ }^{\text {46 }}$ Tetapi itu tidak berarti, bahwa pengetahuan kita direduksi hanya pada apa yang secara empiris dapat dibuktikan. Dengan demikian status serta jasa ilmu-ilmu empiris (ilmu-ilmu alam) sama sekali tidak disangkal dan dikritik, melainkan godaan saientisme yang ada di baliknya. Dengan kata lain, naturalisme dikritik Habermas karena di situ orang memberi status metafisika pada apa yang merupakan hasil ilmu pengetahuan empiris. "Ontologisasi atas hasil dari ilmu pengetahuan alam sehingga menjadi suatu pandangan naturalistis tentang dunia ... bukanlah ilmu pengetahuan, melainkan metafisika yang buruk."47 Atau dalam versi yang lain: „Kepercayaan saientistis terhadap ilmu pengetahuan ... bukanlah ilmu pengetahuan lagi, melainkan filsafat yang buruk. “48

Sampai di sini kita dapat melihat, bagaimana teologi dalam dialog dengan cara berpikir (filsafat) tertentu dapat menunjukkan relevansi iman pada masyarakat kontemporer dan mengambil sikap/posisi tertentu terhadap perkembangan aktual yang sedang terjadi. Berdasarkan kekayaan iman, Ratzinger/Benediktus XVI - seperti juga Habermas mengambil sikap kritis tetapi sekaligus prihatin terhadap perkembangan masyarakat modern serta paham akal budi yang menyertainya.Tentu saja tidak boleh dilupakan, bahwa keduanya mengajukan jalan keluar yang berbeda. Benediktus XVI melihat pemecahannya dalam model sintesa iman dan akal budi dalam pemikiran Agustinus dan Thomas Aquinas. Habermas menegaskan, bahwa langkah kembali seperti itu tidak

\footnotetext{
45J. Habermas, Zwischen Naturalismus und Religion. Philosophische Aufsaetze, Frankfurt am Main: Suhrkamp Verlag, 2005, hlm. 7.

${ }^{46} \mathrm{~J}$. Habermas, Religion in der Oeffentlichkeit. Kognitive Voraussetzungen fuer den oeffentlichen Vernunftgebrauch religioeser und saekularer Buerger, in: Zwischen Naturalismus und Religion, 119-154: 147.

${ }^{47} \mathrm{~J}$. Habermas, Ich selber bin ja ein Stück. Natur-Adorno über die Naturverflochtenheit der Vernunft, dalam: J. Habermas, Zwischen Naturalismus und Religion, 187-215: 215.

48J. Habermas, Glauben und Wissen. Dankesrede des Friedenspreisträgers, dalam: http://www.glasnost.de/docs01/011014 habermas.htiml; diakses pada 3 Februari 2007, pukul 12. 35.
} 
dimungkinkan lagi. „Pihak orang beragama harus mengakui otoritas akal budi kodrati ... Sebaliknya akal budi sekular tidak dapat menjadi hakim atas kebenaran-kebenaran iman ... Ilmu pengetahuan modern telah mendorong akal budi filosofis yang telah menjadi kritis untuk meninggalkan konstruksi metafisis keseluruhan tentang alam dan sejarah ... Dengan demikian sintesa antara iman dan pengetahuan sebagaimana dibuat oleh Agustinus dan Thomas dihancurkan."49

b. Dialog antara J.B. Metz dengan Walter Benjamin: Konsep teologis memoria passionis dikembangkan Metz dalam rangka mengingatkan kita untuk bersolider juga dengan mereka yang sudah menjadi korban. Kelemahan ideologi-progress (pembangunan) pada jaman modern adalah bahwa dengan itu orang bisa bersolider dengan generasi masa depan, tetapi tidak memberi tempat pada solidaritas dengan mereka yang menjadi korban sejarah. Bersama Walter Benjamin, Metz menegaskan, bahwa prinsip ideologis pembangunan modern terletak dalam hal ini: demi kemajuan/masa depan, maka tumbal itu sah-sah saja.

Akan tetapi, kalau penderitaan mereka di masa lalu/mereka yang sudah menjadi korban tidak mau kita benarkan/sahkan begitu saja demi kebahagiaan (orang lain) di masa depan, maka muncul pertanyaan tentang bagaimana mereka yang sudah mati itu masih bisa diselamatkan? Demi masa depan, ideologi modern tentang progress (pembangunan) tidak mau peduli dengan nasib mereka yang sudah menjadi korban. Seperti sudah ditegaskan, Benjamin dengan teorinya tentang memoria menegaskan, bahwa juga dengan yang mati kita harus solider. Dan itu berarti mereka menuntut untuk diselamatkan. Sebagai filosof, Benjamin berhenti sampai di sini. Dan justru di sini letak perbedaannya dengan Metz. Kenangan solider dengan mereka yang sudah menjadi korban secara prinsipiil tetap tanpa harapan - demikian Metz - kalau tidak diberi dasar teologis. Kenangan seperti itu memang dapat berperan penting untuk bekerja lebih baik demi masa depan, tetapi tidak bisa menyelamatkan mereka yang sudah menjadi korban. Harapan akan diselamatkannya mereka yang sudah mati hanya dapat hidup berkat

${ }^{49} \mathrm{~J}$. Habermas, Ein Bewusstsein von dem, was fehlt, hlm. 48-49. Bdk. J. Habermas, Replik auf Einwaende, Reaktion auf Anregungen, hlm. 366-414. 
memoria passionis, mortis et resurrectionis. Memoria seperti itu tidak hanya mengingatkan orang akan mereka yang sudah mejadi korban, tetapi juga percaya bahwa mereka dapat diselamatkan, karena subjek eskatologis sejarah akhirnya adalah Allah sendiri. Harapan akan kebangkitan mereka yang sudah mati, yang mendapatkan dasarnya dalam kebangkitan Yesus Kristus, mencegah bahwa sejarah hanya menjadi sejarah para pemenang saja.

\section{Catatan Penutup}

Demi mencapai hasil yang berguna, dalam dialog antara filsafat dan teologi perlulah masing-masing pihak sadar akan metodologi ilmunya masing-masing dan secara konsisten bekerja berdasarkan prinsip-prinsip metodologis tersebut. Dengan demikian kita akan terhindar dari bahaya jatuh ke dalam pembuatan klaim-klaim yang melampaui batas kewenangan masing-masing ilmu. Begitu pula dengan demikian filsafat dan teologi tidak akan jatuh pada bahaya saling merekapitulasi satu sama lain.

Dapat diduga bahwa terdapat beragam posisi dan pandangan di antara para teolog tentang filsafat. Di kalangan para teolog hingga sekarang pun misalnya terdapat perbedaan pandangan tentang filsafat modern (yang kendati mengandung unsur-unsur dasar sama tetapi juga sangat bervariasi). Ada yang lebih memiliki sikap positif terhadap arus pemikiran modern dan berpandangan, bahwa teologi harus berdialog secara terbuka dengannya. „Plato, Aristoteles, Thomas tetap akan menjadi filsuf yang hidup. Dari mereka kita harus belajar. Akan tetapi hal itu tidak mengubah kenyataan, ... bahwa filsafat sekarang ini dan bersama itu juga teologi tidak dapat dan tidak boleh begitu saja kembali ke jaman lalu, seolah-olah belum terjadi pembalikan antropologis-transendental dalam filsafat modern sejak Descartes, Kant, melalui idealisme Jerman ... hingga fenomenologi, filsafat eksistensial dan ontologi fundamental.“50 Bahkan ada yang berkeyakinan, bahwa kesadaran modern tentang manusia sebagai subjek yang bebas tidak lain merupakan perwujudan

50 K. Rahner, Theologie und Anthropologie, in: ders.,Schriftenzur Theologie VIII,Einsiedeln/Zürich/Köln 1967, 43-65: 56. 
nyata dari iman Kristen mengenai penciptaan dan inkarnasi. ${ }^{51}$ Di samping itu ada pula yang bersikap lebih hati-hati: Di satu pihak tidak ingin "kembali ke zaman sebelum Pencerahan dan meninggalkan sama sekali pandangan-pandangan modern", 52 tetapi di lain pihak merindukan lagi sintesis abad pertengahan tentang iman dan pengetahuan sebagaimana misalnya dibuat oleh Thomas Aquinas. ${ }^{53}$ Sejumlah teolog bersikap skeptis terhadap gagasan post-modern tentang kematian subjek (misalnya karena dalam kekristenan, subjek menduduki peran sentral), tentang penolakan atas grand-narrative (karena kekristenan sendiri adalah sebuah grand-narrative), tentang 'the end of history' (bdk. Pandangan kristiani yang eskatologis tentang sejarah), ${ }^{54}$ tentang sikap skeptis atas kemampuan akal budi dalam mencari kebenaran ${ }^{55}$ dll. Sejumlah teolog lain justru merasa menemukan dalam pemikiran post-modern peluang untuk memahami kekristenan dengan lebih baik. ${ }^{56}$

\footnotetext{
${ }^{51}$ Gagasan ini misalnya pernah dilontarkan J.B. Metz pada periode awal dari teologinya. Tentu saja klaim semacam ini menimbulkan perdebatan pro-kontra yang sengit.

${ }^{52}$ Benediktus XVI, 'Glaube, Vernunft und Universitaet: Erinnerungan und Reflexionen,' dalam: http://www.zenit.org/article-10336. Diakses pada hari Senin, 18 Juni 2007, pukul 11.35 WIB.

${ }^{53}$ Misalnya posisi Yohanes Paulus II dalam ensiklik 'Fides et Ratio'.

${ }^{54} \mathrm{~W}$. Kasper, Die Kircheangesichts der Herausforderung der Postmoderne, dalam: Stimmen der Zeit 10 (1997), hlm. 651-664

${ }^{55}$ Itulah sebenarnya keprihatinan yang melatarbelakangi lahirnya ensiklik 'Fides et Ratio'. Ensiklik tersebut bermaksud „di tengah dunia yang ditandai dengan relativisme, menghidupkan kembali pertanyaan/pencarian akan kebenaran ..."J. Ratzinger, GlaubeWabrheit-Toleranz: Das Christentum und die Weltreligionen, Freiburg-Basel-Wien: Herder Verlag 2003, hlm. 149. Gejala akal budi yang sedang sakit nampak menurut Ratzinger dalam hal ini, bahwa segala upaya untuk menegaskan kembali kemampuan akal budi untuk mencari kebenaran dipandang sebagai fundamentalisme yang akan melahirkan orang-orang fanatik. Yang perlu dilakukan kemudian adalah „dekonstruksi sebagaimana ditunjukkan oleh Jacques Derrida: Ia telah mendekonstruksi prinsip ramah kepada tamu, mendekonstruksi demokrasi, negara dan akhirnya konsep terorisme, tetapi tokh kemudian terkejut oleh peristiwa 11 September."J. Ratzinger, Werte,132-133.

${ }^{56}$ Bdk. Peter Hardt/Klaus von Stosch (Hg.), Fuer eine schwache Vernunft? Beitraege zu einer Theologie nach der Postmoderne, Ostfildern: Matthias-Gruenewald Verlag 2007; Gregor Maria Hoff, Die PrekaereIdentitaet des Christlichen. Die HerausforderungpostModernenDifferenzdenkensfuereinetheologischeHermeneutik, Paderborn-Muenchen-Wien-Zuerich: Ferdinand Schoeningh 2001; Graham Ward (Editor), The Postmodern God: A Theological Reader, Massachusetts-Oxford: Blackwell Publishers Ltd 2002. John D. Caputo and Michael J. Scanlon (Eds.), Transcendence and Beyond. A Postmodern Inquiry, Bloomington and Indianapolis: Indiana University Press 2007.
} 
Penilaian tentang posisi mana yang paling dapat dipertanggungjawabkan akan ditentukan paling tidak oleh tiga faktor berikut: ketepatan pemahaman sang teolog akan filsafat tertentu yang merupakan partner dialog, pemahamannya sendiri tentang kekayaan peristiwa wahyu yang merupakan acuan setiap teologi, dan konsistensi dalam bekerja sesuai dengan prinsip-prinsip metodologis masing-masing ilmu.

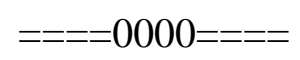

Tulisan ini pernah dimuat sebagai ekskurs dalam buku saya, yaitu A. Sunarko, ofm, Teologi Fundamental, Yogyakarta: Penerbit Lamalera 2013, 161-188. 


\section{DAFTAR PUSTAKA}

John D. Caputo and Michael J. Scanlon (Eds.). Transcendence and Beyond. A Postmodern Inquiry. Bloomington and Indianapolis: Indiana University Press 2007.

P. Eicher,Offenbarung. Prinzip Neuzeitlicher Theologie. Muenchen: KoeselVerlag 1977.

J. Habermas. Zur Logik der Sozialwissenschaften. Tuebingen: Mohr 1967.

J. Habermas. Der Universalitaetsanspruch der Hermeneutik, in: ders., Kultur und Kritik. Frankfurt: Suhrkamp Verlag 1973, 264-301.

J. Habermas. "Transzendenz von innen: Lebensweltliche und archaische Bewaeltigung des Dissensrisikos”, in: Faktizität und Geltung. Beiträge zur Diskurstheorie des Rechts und des demokratischen Rechtsstaats. Frankfurt am Main : Suhrkamp Verlag 1992, 32-44.

J. Habermas. Zu Max Horkheimers Satz: <<Einen Unbedingten Sinn zu retten ohne Gott, ist eitel<<, in: J. Habermas. Text und Kontexte. Frankfurt am Main: Suhrkamp Verlag, 1992, 110-126.

J. Habermas. Zwischen Naturalismus und Religion. Philosophische Aufsaetze. Frankfurt am Main: Suhrkamp Verlag, 2005.

J. Habermas. Ich selber bin ja ein Stück Natur - Adorno über die Naturverflochtenheit der Vernunft, dalam: J. Habermas, Zwischen Naturalismus und Religion, 187-215.

J. Habermas. Religion in der Oeffentlichkeit. Kognitive Voraussetzungen fuer den oeffentlichen Vernunftgebrauch religioeser und saekularer Buerger, dalam: J. Habermas, Zwischen Naturalismus und Religion, 119-154.

J. Habermas. Pre-political Foundations of the Democratic Constitutional State?, in: J.Habermas/J. Ratzinger. The Dialectics of Secularization. On Reason and Religion (Translated by Brian McNeil, C.R.V.). San Francisco: Ignatius Press, 2006, 19-52. 
J. Habermas. Ein Bewusstsein von dem, was fehlt. Über Glauben und Wissen und den Defätismus der modernen Vernunft, dalam: K. Wenzel (Hrsg.). Die Religion und die Vernunft. Die Debatte um die Regensburger Vorlesung des Papstes. Freiburg/Basel/Wien: Herder Verlag, 2007, 47-56.

J. Habermas. Replik auf Einwände.Reaktion auf Anregungen, in: R. Langthaler/H. Nagl-Docekal (Hrsg.). Glauben und Wissen. Ein Symposium mit Jürgen Habermas. Wien-Berlin: Oldenbourg-Akademie Verlag, 2007, 366-414.

Peter Hardt/Klaus von Stosch (Hg.). Fuer eine schwache Vernunft? Beitraege zu einer Theologie nach der Postmoderne. Ostfildern: Matthias-Gruenewald Verlag 2007.

Gregor Maria Hoff. Die Prekaere Identitaet des Christlichen. Die Herausforderung postModernen Differenzdenkens fuer eine theologische Hermeneutik. Paderborn-Muenchen-Wien-Zuerich: Ferdinand Schoeningh 2001.

I. Kant. Die Religion innerhalb der Grenzen der blossen Vernunft (Hrsg. v. Rudolf Mater). Stuttgart: Philipp Reclam Jun 1974.

W. Kasper. Der Gott Jesu Christi. Mainz: Matthias-Gruenewald-Verlag 1995.

W. Kasper. Die Kircheangesichts der Herausforderung der Postmoderne, dalam: Stimmen der Zeit 10 (1997), 651-664.

L. Leahy SJ. Filsafat Ketuhanan Kontemporer, Jogjakarta: Kanisius/BPK Gunung Mulia, 1994.

K.-H. Menke. Stellvertretung: Schlüsselbegriff christlichen Lebens und theologische Grundkategorie. Einsiedeln-Freiburg: Yohanes Verlag 1997.

J.B. Metz. Zur Theologie der Welt. Mainz: Matthias-Gruenewald Verlag 1985.

W. Pannenberg. Anthropologie in theologischer Perspektive. Göttingen: Vandenhoeck und Ruprecht 1983. 
Y. Paulus II. Fides et Ratio. Jakarta: DokPen KWI 2009.

H. Peukert.Wissenschaftstheorie. Handlungstheorie. Fundamentale Theologie. Analysen zu Ansatz und Status theologischer Theoriebildung. Frankfurt am Mainz: Suhrkamp 2009.

K. Rahner. SchriftenzurTheologie I. Einsiedeln/Zürich/Köln: Benzinger 1967.

K. Rahner. Theologie und Anthropologie, dalam: ders., Schriftenzur Theologie VIII, Einsiedeln/Zürich/Köln: Benzinger 1967, 43-65.

K. Rahner. Hoerer des Wortes. Zur Grundlegung einer Religionsphilosophie (Neu bearbeitet von Johannes Baptist Metz). Freiburg-Basel-Wien: Herder 1971.

J. Ratzinger. Glaube-Wahrheit-Toleranz. Das Christentum und die Weltreligionen. Freiburg-Basel-Wien: Herder Verlag 2003.

J. Ratzinger. Werte in Zeiten des Umbruchs. Die Herausforderungen der Zukunft bestehen. Freiburg/Basel/Wien: Herder Verlag, 2005.

J. Ratzinger/Benedikt XVI. Jesus von Nazareth. Band II. Von Einzug in Jerusalem bis zur Auferstehung. Freiburg/Basel/Wien: Herder 2011.

E. Schillebeeckx. Glaubensinterpretation. Beitraege zu einer hermeneutischen und kritischen Theologie. Mainz: Matthias-Gruenewald Verlag 1971.

E. Schillebeeckx. Theologisch geloofsverstaan anno 1983. Baarn 1983.

M. Striet. Versuch über die Auflehnung: Philosophisch-theologische Überlegungenzur Theodizeefrage, dalam: H. Wagner (Hg.), MitGottstreiten. NeueZugängezumTheodizeeproblem (= QD 168), Freiburg: Herder, 1998, S. 48-89.

M.Striet. Das Versprechen der Gnade, dalam: Th. Proepper, Theologische Anthropologie. ZweiterTeilband, Freiburg-Basel-Wien: HerderVerlag 2011, 1490-1520. 
J.-H., Tück. Christologie und Theodizeebei Johann Baptist Metz. Ambivalenz der NeuzeitimLicht der Gottesfrage. Paderbon/München/Wien/Zürich: Schöningh, 1999.

Graham Ward (Editor). The Postmodern God. A Theological Reader.

Massachusetts-Oxford: Blackwell Publishers Ltd 2002.

Sumber dari Internet:

Benediktus XVI, Glaube, Vernunft und Universitaet. Erinnerungen und Reflexionen, dalam: http://www.zenit.org/article-10336. Diakses pada hari Senin, 18 Juni 2007, pukul 11.35 WIB.

J. Haberm as, Glauben und Wissen. Dankesrede des Friedenspreisträgers, dalam: http://www.glasnost.de/docs01/011014 habermas.htiml; diakses pada 3 Februari 2007, pukul 12.35. 